\title{
NILAI-NILAI PENDIDIKAN KARAKTER PADA NOVEL SIMPLE MIRACLES KARYA AYU UTAMI
}

\author{
Teguh Alif Nurhuda', Herman J. Waluyo², Suyitno ${ }^{3}$ \\ Program Studi Magister Pendidikan Bahasa Indonesia, FKIP \\ Universitas Sebelas Maret \\ Surel: teguhalifnurhuda@gmail.com
}

\begin{abstract}
Abstrak
Penelitian ini bertujuan untuk mendeskripsikan nilai-nilai pendidikan karakter yang terdapat pada novel Simple Miracles karya Ayu Utami. Penelitian ini menggunakan meode deskriptif kualitatif dengan subjek novel Simple Miracles. Novel karya Ayu Utami ini menceritakan tentang kehidupan satu keluarga dan tentang kematian beberapa anggota keluarga. Hasil dari penelitian ini dapat disimpulkan dari 18 nilai pendidikan karakter yang ditentukan oleh pemerintah terdapat sepuluh nilai pendidikan karakter di dalam novel tersebut, di antaranya religius, jujur, toleransi, mandiri, demokratis, rasa ingin tahu, bersahabat, gemar membaca, peduli sosial, dan tanggung jawab.
\end{abstract}

Kata kunci: Pendidikan karakter, novel, simple miracles.

\section{Abstact}

This study aims to describe the values of character education contained in the novel Simple Miracles by Ayu Utami. This research uses qualitative descriptive method with the subject of Simple Miracles novel. Ayu Utami's novel tells about the life of one family and about the deaths of several family members. The results of this study can be concluded from the 18 values of character education determined by the government there are ten values of character education in the novel, among them religious, honest, tolerant, independent, democratic, curiosity, friendly, likes to read, social care, and responsible.

Keywords: character, novel, simple miracles.

\section{PENDAHULUAN}

Novel sebagai salah satu bentuk karya sastra diharapkan memunculkan nilai-nilai positif bagi penikmatnya, sehingga mereka peka terhadap masalah-masalah yang berkaitan dengan kehidupan sosial dan mendorong untuk berperilaku yang baik. Novel juga merupakan ungkapan fenomena sosial dalam aspek-aspek kehidupan yang dapat digunakan sebagai sarana mengenal manusia dan zamannya.
Noveb dapat digunakan untuk mengangkat kehidupan, baik beberapa individu maupun masyarakat luas. Pancaran kehidupan sosial dan gejolak kejiwaan pengarang terhadap kenyataan yang ditemukan dalam masyarakat, biasanya berbentuk peristiwa, norma, dan ajaran-ajaran agama. Novel yang semakin bersinar di masa kini tak lain adalah cerita yang berkelanjutan tentang manusia yang dipoles 
sedemikian rupa oleh penulis-penulis yang kreatif.

Sebuah novel yang baik adalah novel yang mampu diresapi dan dapat memunculkan nilai-nilai yang positif. Nilai-nilai positif di sini dapat diartikan sebagai nilai pendidikan karakter. Pendidikan karakter adalah sistem penanaman nilai-nilai karakter kepada warga sekolah meliputi komponen pengetahuan, kesabaran atau kemampuan, dan tindakan untuk melaksanakan nilai-nilai tersebut (Aqib, 2012:3). Pengarang secara sadar maupun tidak sadar pastinya menuliskan nilai-nilai pendidikan karakter secara tersirat maupun tersurat. Novel Simple Miracles Doa dan Arwah karya Ayu Utami menceritakan tentang kehidupan tokoh utama dengan keluarganya. Proses interaksi terjadi di antara tokoh-tokoh yang ada di dalam novel tersebut. Selain menceritakan kehidupan tokoh utama, di dalam novel tersebut juga menceritakan adat jawa yang memandang kehidupan dan kematian. Jelas di dalam novel karya Ayu Utami tersebut juga memiliki nilai pendidikan karakter yang, seperti kepatuhan terhadap orang tua.

Menurut Suyanto (2010:1), individu yang berkarakter baik bisa membuat keputusan dan siap mempertanggungjawabkan setiap akibat dari keputusan yang ia buat. Kemendiknas sudah merumuskan tujuan pendidikan karakter untuk berkembangnya potensi peserta didik agar menjadi manusia yang beriman dan bertakwa kepada Tuhan Yang Maha Esa, berakhlak mulia, sehat, berilmu, cakap, kreatif, mandiri, dan menjadi warga negara yang demokratis serta bertanggung jawab. Pendidikan karakter merupakan pendidikan yang mengembangkan nilai-nilai budaya dan karakter bangsa pada diri siswa, sehingga mereka memiliki dan menerapkan nilai-nilai tersebut dalam kehidupan dirinya sebagai anggota masyarakat dan warga negara yang relegius, produktif, dan kreatif (Sulistyowati, 2013:22). Fungsi dan tujuan pendidikan nasional yang dirumuskan kemendiknas, jelas bahwa pendidikan karakter di setiap jenjang pendidikan, khususnya di sekolah harus diselenggarakan secara sistematis guna mencapai tujuan tersebut. Ditambah lagi tentang kurikulum yang saat ini sedang digunakan, yaitu kurikulum 2013 yang menitikberatkan segala aspek pendidikan untuk menyisipkan nilai-nilai pendidkan karakter. Wibowo (2013:16) mengatakan bahwa pendidikan karakter yang terintegrasi dalam proses pembelajaran, artinya pengenalan nilai-nilai, kesadaran akan pentingnya nilai-nilai, dan penginternalisasian nilai-nilai ke dalam tingkah laku peserta didik melalui proses pembelajaran baik yang berlangsung di dalam maupun di luar kelas.

\section{METODE}

Penelitian ini merupakan penelitian kualitatif dengan desain deskriptif, yaitu penelitian yang memberi gambaran secara cermat mengenai individu atau kelompok tertentu tentang keadaan dan gejala yang terjadi. Ratna (2013:47) berpendapat bahwa penyajian dan penafsiran metode kualitatif yakni dalam bentuk deskriptif. Hal tersebut berarti bahwa data yang dihasilkan berupa kata-kata dalam bentuk kutipan-kutipan. Metode tersebut digunakan untuk menelaah isi dari suatu novel. Novel dalam penelitian ini adalah novel Simple Miracles karya Ayu Utami. Adapun hal-hal yang dideskripsikan dalam penelitian 
ini yaitu mengenai nilai pendidikan karakter dalam novel Simple Miracles karya Ayu Utami.

Data dalam penelitian ini berupa kutipan teks yang berbentuk kata-kata dan kalimat yang sesuai dengan kajian utama penelitian ini. Data yang ditampilkan tersebut merupakan data yang runtut dan sesuai dengan alur cerita di dalam Simple Miracles karya Ayu Utami. Sedangkan sumber data dalam penelitian ini adalah novel Simple Miracles karya Ayu Utami. Sumber data tersebut pada hakikatnya berperan sebagai bahan pemerolehan data yang akan dianalisis.

Validasi data atau keabsahan data dalam penelitian ini dengan cara mengumpulkan data. Data yang diperoleh, dikumpulkan, dan dicatat dalam kegiatan penelitian dipilih dengan tepat dalam mengembangkan validitas data yang diperoleh. Validitas data yang dikumpulkan dalam penelitian ini mempergunakan teknik triangulasi data. Moleong (2013:330) mengungkapkan bahwa triangulasi adalah teknik pemeriksaan keabsahan data yang memanfaatkan sesuatu yang lain.

\section{HASIL DAN PEMBAHASAN}

Pendidikan karakter adalah pendidikan yang menanamkan dan mengembangkan karakter-karakter luhur kepada anak didik, sehingga mereka memiliki karakter luhur tersebut. Diharapkan para anak didik mampu menerapkan nilai-nilai luhur tersebut dan mempraktikkan dalam kehidupannya, dalam keluarga, sebagai anggota masyarakat dan warga negara. Pendidikan karakter bertujuan untuk membentuk penyempurnaan diri individu secara terus-menerus dan melatih kemampuan diri demi menuju ke arah hidup yang lebih baik. Penguatan pen- didikan moral atau pendidikan karakter dalam konteks sekarang sangat relevan untuk mengatasi krisis moral yang sedang melanda di negara kita.

Beberapa ahli juga berpendapat mengenai pendidikan karakter. Menurut Banawi (2013:22) pendidikan karakter merupakan pendidikan ihwal karakter, atau pendidikan yang mengajarkan hakikat karakter dalam tiga ranah cipta, rasa, dan karsa. Lain halnya dengan Banawi, Kemendiknas (2010:11) menjelaskan guru dan pemangku kebijakan pendidikan di sekolah perlu mengintegrasikan nilai-nilai yang dikembangkan dalam pendidikan karakter ke dalam kurikulum, silabus, dan Rencana Pelaksanaan Pembelajaran (RPP). Selain itu, menurut Wibowo (2013:36) dalam pendidikan karakter di sekolah semua komponen pemangku kepentingan harus dilibatkan. Seperti kurikulum proses pembelajaran dan penilaian, penanganan dan pengelolaan mata pelajaran, pelaksanaan aktivitas dan pengelolaan sekolah dengan tujuan penyelenggaraan pendidikanya dilandasi dengan karakter.

Menurut Ratna (2014:73) menjelaskan bahwa pendidikan karakter sama halnya dengan membersihkan saraf dari berbagai anomali, semacam 'cuci otak', sehingga pikiran dan perasaan setiap individu dapat diarahkan pada tujuan-tujuan yang bersifat positif. Pendidikan karakter diartikan sebagai hal positif yang dapat dilakukan oleh guru ataupun dosen dan berpengaruh kepada karakter siswa yang diajar (Samani, 2012: 43). Sudrajat (dalam Suwandi, 2011: 2), menyatakan bahwa karakter merupakan nilai-nilai perilaku manusia yang berhubungan dengan Tuhan Yang Maha Esa, diri sendiri, sesama manusia, 
lingkungan, dan kebangsaan yang terwujud dalam pikiran, sikap, perasaan, perkataan, dan perbuatan berdasarkan norma-norma agama, hukum, tata karma, budaya dan adat istiadat.

Novel Simple Miracles menceritakan kisah spiritual tokoh utama dan keluarganya dalam kehidupan seharihari. Selain itu di dalamnya juga diceritakan tentang hubungan masyarakat yang berkaitan dengan keagamaan, sosial, budaya, dan tempat tinggal. Garis besar cerita yang disuguhkan di dalam novel tersebut bercerita tentang kisah kematian ibu dari tokoh utama. Selain itu juga menceritakan kisah spiritual dari beberapa tokoh. Alur dari cerita novel tersebut beralurkan alur maju. Latar tempat beragam karena tokoh menceritakan kisahnya dari tokoh utama masih kecil sampai Ibu dari tokoh utama meninggal, tetapi latar tempat terfokus di Jakarta.

Berdasarkan analisis yang dilakukan pada novel Simple Miracles karya Ayu Utami dapat disimpulkan bahwa nilai pendidikan karakter yang ditemukan ada sepuluh nilai pendidikan karakter. Nilai-nilai pendidikan karakter tersebut adalah religius, jujur, toleransi, mandiri, demokratis, rasa ingin tahu, bersahabat, gemar membaca, peduli sosial, dan tanggung jawab. Penulis dalam menyampaikan nilai-nilai pendidikan karakter di dalam novel tersebut disampaikan secara tersurat maupun tersirat. Berikut sepuluh nilai pendidikan karakter yang ditemukan di dalam novel Simple Miracles karya Ayu Utami.

\section{Religius}

Religius, beribadah sesuai agama yang dianut dan patuh dalam mengerjakan perintah agama, toleran terhadap pelaksanaan ibadah agama lain, dan hidup rukun dengan pemeluk agama lain. Dalam novel Simple Miracles nilai religius tercermin dalam keberagaman agama yang dianut oleh keluarga dari tokoh utama dan beberapa tokoh lain. Tokoh utama dan keluarganya merupakan pemeluk agama Katolik. Selain agama Katolik, agama lain seperti agama Islam juga ada di dalam cerita novel tersebut. Di dalam novel tersebut dijelaskan tentang kepercayaan agama Katolik dan Islam dalam menyikapi kematian. Menyikapi dalam hal ini berupa kepercayaan-kepercayaan tentang hari dan tradsi setelah kematian. Nilai pendidikan karakter religius di dalam novel Simple Miracles terfokus pada bagaimana tokoh utama menyikapi tentang ketuhanan dan kepercayaan.

Tokoh utama dalam novel tersebut menyikapi bahwa masyarakat Indonesia sedari kecil sudah diajari dan percaya tentang agama dan Tuhan. Ketika beranjak dewasa Tokoh utama tersebut mulai merasa ragu terhadap agama dan Tuhan. Kejadian meninggalnya anggota keluarga seperti Ayah, Ibu, dan Bibi dari tokoh utama membuat tokoh utama mulai meyakini tentang agama dan Tuhan. Anak judul dari novel Simple Miracles ialah doa dan arwah, maka dalam novel tersebut juga banyak menceritakan tentang doa. Ketika tokoh utama sudah beranjak dewasa, dia merasa ragu akan Tuhan dan segala hal keagamaan seperti doa. Setelah ayahnya meninggal, tokoh utama dalam novel tersebut terus merenung jika nanti ibunya meninggal. Semenjak ibunya sakit-sakitan tokoh utama menjadi rajin mendoakan ibunya. Bahkan ibunya meninggal dengan diiringi doa dari tokoh utama. 


\section{Jujur}

Jujur, sikap yang didasarkan pada upaya ingin menjadikan diri sebagai orang yang selalu dapat dipercaya dalam perkataan dam tindakan. Nilai pendidikan karakter jujur juga ada dalam novel karangan Ayu Utami tersebut. Nilai kejujuran diceritakan dari beberapa sudut pandang tokoh-tokoh yang ada di novel Simple Miracles tersebut. Tokoh-tokoh yang mempunyai karakter jujur di dalam novel tersebut yaitu tokoh utama dan keponakannya yang bernama Bonifacius. Nilai kejujuran tokoh utama di dalam novel tersebut ada pada interaksinya dia dengan Ibu dan temannya. Sedangkan Bonifacius merupakan tokoh yang mempunyai kelebihan berupa dapat melihat arwah dan hantu serta dapat menemukan barang yang hilang. Suatu ketika Bonifacius ketika masih sekolah bertemu dengan roh siswa lain dan orang-orang di sekitarnya tidak percaya walau Bonifacius sudah jujur tentang apa yang dia lihat.

\section{Toleransi}

Toleransi merupakan tindakan menghargai perbedaan agama, suku, etnis, pendapat, sikap, dan tindakan orang lain yang berbeda dari dirinya. Di dalam novel tersebut menceritakan tentang toleransi beragama atau keya kinan. Seperti ketika tokoh utama bertamu ke rumah temanya yang berkepercayaan Tionghwa, di rumah temannya ada sebuah ruangan khusus untuk beribadah dan tokoh utama menelaah dan menghargai kepercayaan temannya tersebut. Telaah yang dilakukan tokoh utama berupa menyikapi bahwa tiap agama memiliki kepercayaan dan tradisi masingmasing. Tokoh utama menganggap perbedaan dalam memeluk agama hanya lain berbeda dalam subtansi tetapi masih memiliki esensi yang sama. Toleransi beragama juga dialami tokoh utama dengan temannya yang beragama Islam. Tokoh utama menghargai pendapat dari temannya yang menganggap konsep tentang kelahiran merupakan konsep dari Islam.

Sikap toleransi beragama juga dapat dilihat dari kehidupan keluarga tokoh utama seperti ketika ayahnya mengizinkan kakaknya menikah dengan yang tidak seagama. Ayahnya memiliki prinsip boleh menikah beda agama tetapi dia tidak mengizinkan anaknya pindah agama dan tidak meminta menantunya pindah agama pula. Pada akhirnya kakak dari tokoh utama tersebut menikah dengan laki-laki Muslim dan mencatatkan pernikahan mereka secara Islam di Kantor Urusan Agama. Selain itu mereka juga melakukan pemberkatan Katolik. Pada akhirnya kakak dari tokoh utama dan suaminya tetap pada kepercayaan masing-masing.

\section{Mandiri}

Mandiri merupakan sikap dan perilaku yang tidak mudah tergantung pada orang lain dalam menyelesaikan tugas-tugas. Sikap mandiri yang diceritakan dalam novel Simple Miracles diceritakan dari beberapa sudut pandang Sikap mandiri dimiliki oleh tokoh utama yang setelah dewasa ia mulai sadar bahwa ketika masih kecil dia bergantung pada orang dewasa. Ketika masih kecil ia selalu membutuhkan ibunya dan merasa rindu jika tidak bertemu tetapi ketika sudah dewasa ia sudah merasa tidak rindu lagi pada ibunya walau tidak bertemu. Pendidikan karakter mandiri juga diceritakan secara tersirat dalam novel karya Ayu Utami tersebut. Seperti 
ketika ayahnya mendidik anak-anaknya untuk menjadi perempuan yang mandiri. Hal tersebut disadari tokoh utama ketika ia sudah beranjak dewasa.

\section{Demokratis}

Demokratis merupakan cara berpikir, bersikap, dan bertindak yang menilai sama hak dan kewajiban dirinya dan orang lain. Demokratis juga merupakan gagasan atau pandangan hidup yang mengutamakan persamaan hak dan kewajiban serta perlakuan yang sama bagi sesama. Sikap demokratis juga bisa diartikan sebagai menghargai gagasan dan juga pendapat orang lain. Dalam novel Simple Miracles diceritakan tentang perbedaan pendapat tetapi dari perbedaan tersebut juga ada sikap menghargai pendapat yang berbeda. Tokoh-tokoh yang memiliki sikap demokratis paling dominan di dalam novel tersebut adalah tokoh utama. Salah satu sikap demokratisnya ketika memiliki keraguan terhadap cerita hantu-hantu dari Bibi Gemuk dan Kurusnya.

Selain itu sikap demokratis juga terlihat ketika tokoh utama menyikapi cerita keponakannya yang bisa melihat hantu atau roh. Pada akhirnya tokoh utama menyikapi untuk percaya karena dia takut kalau tidak ada yang percaya pada keponakannya. Selain tokoh utama, sikap demokratis juga terlihat dari keputusan Ayahnya soal pernikahan kakaknya dengan calon suaminya yang bukan dari agama Katolik. Ayah dari tokoh utama mengambil sikap untuk membiarkan anaknya menikah dengan lelaki yang beragama Islam tetapi Ayahnya tidak menyuruh calon menantunya pindah agama ke agama Katolik. Akhirnya anaknya menikah dengan mencatat- kan pernikannya secara Islam di Kantor Urusan Agama dan setelah itu mengadakan pemberkatan Katolik.

\section{Rasa Ingin Tahu}

Rasa ingin tahu merupakan sikap dan tindakan yang selalu berupaya untuk mengetahui lebih mendalam dan meluas dari sesuatu yang dipelajarinya, dilihat, dan didengar. Sikap rasa ingin tahu di dalam novel Simple Miracles merupakan nilai pendidikan karakter yang paling dominan. Rasa ingin tahu nampak ketika tokoh utama membayangkan ibunya meninggal di usia muda dan anak-anaknya masih kecil lalu apakah ibunya menjadi arwah penasaran. Hal tersebut menjadikan tokoh utama memiliki rasa ingin tahu terhadap kematian. Rasa ingin tahu tokoh utama juga terlihat ketika ia berpikir bahwa jasad tidak bergerak tetapi roh hidup dan apa yang dilakukan oleh roh yang hidup. Hal tersebut menjadikan rasa ingin tahu dari tokoh utama.

Selain itu rasa ingin tahu juga muncul ketika tokoh utama diberi cerita oleh Bibinya tetapi cerita tersebut tidak selesai diceritakan. Rasa ingin tahu juga muncul ketika keponakan tokoh utama, Bonifacius, dapat melihat hantu dan roh lalu tokoh utama penasaran dengan bentuk dari makhluk yang tidak dapat dilihat manusia biasa tersebut. Kemudian tokoh utama menanyakan tentang perbedaan arwah dengan manusia karena ia penasaran berkaitan dengan bentuk makhluk halus tersebut. Hal tersebut membuktikan bahwa tokoh utama memiliki sifat rasa ingin tahu tentang kematian.

Dalam novel Simple Miracles tokoh utama juga memiliki rasa ingin tahu tentang Tuhan. Tokoh utama berpikir kenapa manusia sakit dan mati, 
Tuhan maunya apa, hal tersebut terpikitkan ketika orang tuanya sakit keras. Selanjutnya ia berpikir apakah tuhan itu maha adil dan selanjutnya ia bertanya apakah Tuhan itu ada. Dan pertanyaan yang menurut tokoh utama gawat ialah, untuk apa hidup. Hal tersebut merupakan rasa ingin tahu tokoh utama terhadap Tuhan.

Rasa ingin tahu yang diceritakan dalam novel karya Ayu Utami tersebut juga ada ketika ada orang yang bilang kalau Ibu dari tokoh utama yang sudah meninggal merasa sedih. Lalu orang tersebut mengatakan apakah ada sesuatu peristiwa yang ibunya pendam. Tetapi, tokoh utama berpikir bahwa ibunya merupakan orang yang baik dan tidak pendendam.

\section{Besahabat atau Komunikatif}

Bersahabat atau komunikatif adalah sikap dan tindakan yang mendorong dirinya untuk menghasilkan sesuatu yang berguna bagi masyarakat, dan mengakui, serta menghormati keberhasilan orang lain. Sikap komunikatif terlihat ketika ibunya mengajarkan tentang percaya kepada Tuhan tetapi ragu terhadap hantu. Selain itu ketika tokoh utama dan kakaknya bingung terhadap Bonifacius yang bisa melihat arwah. Akhirnya kakak tokoh utama yang merupakan Ibu dari Bonifacius menceritakan hal tersebut pada ibunya. Hal tersebut membuktikan adanya interaksi di antara tokoh yang ada di dalam novel Simple Miracles.

\section{Gemar Membaca}

Gemar membaca merupakan kebiasaan menyediakan waktu untuk membaca berbagai bacaan yang memberikan kebajikan bagi dirinya. Nilai gemar membaca dalam novel Simple Miracles dimiliki oleh tokoh utama.
Nilai pendidikan gemar membaca terlihat ketika tokoh utama meluangkan waktu untuk membaca Koran Kompas dan ia mengajak keponakannya yang masih kecil untuk melihatlihat koran. Selain itu juga ketika tokoh utama menyadari tentang perkembangan atau pertumbuhannya sendiri dan di dalam kutipan halaman 77 tersebut secara tersurat dikatakan bahwa tokoh utama gemar membaca Alkitab yang menurutnya banyak cerita seru dalam Perjanjian Lama. Hal tersebut menunjukkan bahwa tokoh utama merupakan tokoh yang memiliki sikap gemar membaca.

\section{Peduli Sosial}

Peduli sosial merupakan sikap dan tindakan yang selalu ingin memberi bantuan pada orang lain dan masyarakat yang membutuhkan. Selain itu peduli sosial juga merupakan sikap berinteraksi dengan masyarakat dengan baik. Peduli sosial di dalam novel tersebut dapat dilihat dari berbagai sudut pandang tokoh yang ada di dalam novel. Sikap peduli sosial dimiliki oleh Bibi Gemuk tokoh utama ketika Bibinya mengajak jalan-jalan tokoh utama dan kakaknya waktu kecil kemudian membelikan alat tulis. Hal tersebut merupakan sikap peduli sosial yang dimiliki oleh Bibi Gemuk terhadap keponakan-keponakannya.

Selain itu sikap peduli sosial juga dimiliki oleh tokoh utama ketika dia dan Rik, pasangan hidupnya, menyelamatkan anjing yang dilempari remaja-remaja. Waktu itu tokoh utama dan Rik mengetahui ada anjing yang sedang dianiaya oleh remaja-remaja kompleks tempat mereka tinggal lalu mereka menyelamatkan anjing tersebut kemudian merawatnya. Hal tersebut memperlihatkan bahwa peduli 
sosial juga dapat diberlakukan kepada yang bukan manusia juga. Sikap peduli sosial juga diceritakan ketika Ayahnya sakit kemudian teman dari Ayah tokoh utama datang untuk menjenguk.

\section{Tanggung Jawab}

Tanggung jawab adalah sikap dan perilaku seseorang untuk melaksanakan tugas dan kewajibannya yang seharusnya dia lakukan, terhadap diri sendiri, masyarakat, lingkungannya (alam, sosial dan budaya), negara dan Tuhan Yang Maha Esa. Di dalam novel Simple Miracles terfokus pada cerita dalam satu keluarga maka di dalam novel tersebut nilai pendidikan karakter tanggung jawab di dalamnya juga berkaitan dengan satu keluarga tokoh utama. Salah satu sikap tanggung jawab diperlihatkan oleh kakak tokoh utama yang bertanggung jawab mengurus tokoh utama ketika masih kecil. Selain itu kakak tokoh utama ketika sudah dewasa juga sudah berani berumah tangga yang menandakan dia sudah berani bertanggung jawab akan hidupnya dan hidup keluarganya sendiri.

Sikap tanggung jawab juga diperlihatkan oleh tokoh utama ketika dia sudah berumah tangga tetapi ia masih peduli dengan orang tuanya dengan setidaknya menjenguk orang tuanya yang sakit. Tokoh utama juga peduli dengan anjingnya yang sakit, itu menandakan sikap tanggung jawab kepada hewan. Sikap tanggung jawab juga diperlihatkan oleh anggota keluarga lainnya seperti menantu dari Ibu yang mau merawat Ibu ketika sakit. Ketika Ibu sakit, tokoh utama senantiasa merawat dan mendoakan kesembuhan Ibu. Hal tersebut menun- jukkan tentang sikap tanggung jawab tokoh utama kepada Ibu.

Tidak hanya tokoh utamanya saja yang bertanggung jawab atas Ibunya, tetapi Ibu dari tokoh utama juga bertanggung jawab atas keluarganya. Ibu bertanggung jawab atas anakanaknya, Ibu bertanggung jawab atas suaminya, Ibu juga bertanggung jawab atas kedua saudara iparnya. Dari tokoh utama kecil hingga besar, Ibu selalu peduli terhadap tokoh utama. Ketika Ayah dari tokoh utama sakit, Ibu selalu merawat sampai pada akhirnya Ayah meninggal. Ketika Ibu sakit, Ibu masih sempat khawatir kepada Bibi yang padahal bukan saudaranya melainkan saudara kandung dari Ayah. Hal tersebut menandakan Ibu mempunyai sikap tanggung jawab kepada setiap anggota keluarganya.

\section{PENUTUP}

\section{Simpulan}

Novel Simple Miracles menceritakan kisah spiritual tokoh utama dan keluarganya dalam kehidupan seharihari. Selain itu di dalamnya juga diceritakan tentang hubungan masyarakat yang berkaitan dengan keagamaan, sosial, budaya, dan tempat tinggal. Garis besar cerita yang disuguhkan di dalam novel tersebut bercerita tentang kisah kematian ibu dari tokoh utama. Selain itu juga menceritakan kisah spiritual dari beberapa tokoh. Analisis yang dilakukan pada novel Simple Miracles karya Ayu Utami dapat disimpulkan bahwa nilai pendidikan karakter yang ditemukan ada sepuluh nilai pendidikan karakter. Nilai-nilai pendidikan karakter tersebut adalah religius, jujur, toleransi, mandiri, demokratis, rasa ingin tahu, bersahabat, gemar membaca, peduli sosial, dan tanggung jawab. Penulis 
dalam menyampaikan nilai-nilai pendidikan karakter di dalam novel tersebut disampaikan secara tersurat maupun tersirat.

\section{DAFTAR PUSTAKA}

Aqib, Zainal, dan Sujak. 2012. Panduan dan Aplikasi Pendidikan Ka-rakter. Bandung: Yrama Widya.

Barnawi dan Arifin, M. 2012. Etika dan Profesi Kependidikan. Yogyakarta: Ar-Ruzz Media.

Hidayatullah, F. 2010. Pendidikan Ka-rakter Membangun Peradaban Bangsa. Surakarta: Yuma Pustaka.

Kementerian Pendidikan Nasional. 2010. Desain Induk Pendidikan Karakter. Jakarta Kemendiknas RI.

Kementerian Pendidikan Nasional. 2010. Pengembangan Pendidikan Budaya dan Karakter Bangsa Pedoman Sekolah. Jakarta: Badan Penelitian dan Pengembangan.

Lestyarini, B. 2012. Penumbuhan Semangat Kebangsaan untuk Memperkuat Karakter Indonesia Melalui Pembelajaran Bahasa. Jurnal Pendidikan Karakter. Tahun II Nomor 3, Oktober 2012, 340-354.

Moleong, J. L. 2008. Metodologi Penelitian Kualitatif. Bandung. PT Remaja Rosdakarya.

Muflikhah, Darti, Andayani, dan Raheni Suhita. 2014. Masalah Sosial dalam Novel Air Mata Tjitanduy Karya Bambang Setiaji (Kajian Sosiologi Sastra Dan Pendidikan Karakter). BASASTRA Jurnal Penelitian Bahaa, Sastra Indonesia dan Pengajarannya. 1 (3), 437-447.
Ratna, Nyoman Kutha. 2013. Teori, Metode, dan Teknik Penelitian Sastra. Yogyakarta: Pustaka Pelajar.

Rohman, Saifur. 2012. Pengantar Metodologi Pengajaran Sastra. Yogyakarta: Ar-Ruzz Media.

Rosyidi, Ikhwan., Gumilar, Trisna., Kurniawan, Heru., Zurmailis. 2010. Analisis Teks Sastra. Yogyakarta: Graha Ilmu.

Samani, M. \& Hariyanto. 2012. Konsep dan Model Pendidikan Karakter. Bandung: Remaja Rosdakarya.

Siswantoro. 2010. Metode Penelitian Sastra. Yogyakarta: Pustaka Pelajar.

Sudrajat. 2010. Membangun Budaya Sekolah Berbasis Karakter Terpuji. Pendidikan Karakter dalam Perspektif Teori dan Praktik. Darmiyati Zuchdi (Ed.). Yogyakarta: UNY Press.

Sulistyowati, Endah. 2013. Implementasi Kurikulum Pendidikan Karakter. Yogyakarta: Citra Aji Para-ma.

Suwandi, Sarwiji. 2011. Peran Sastra dalam Pendidikan Karakter bagi Peserta Didik. Makalah Seminar Na-sional Sastra dalam Rangka Pekan Sastra Himprobsi, FKIP UNS.

Wibowo, Agus. 2012. Pendidikan Karakter Strategi Membangun Karakter Bangsa Berperadaban. Yogyakarta: Pustaka Pelajar.

Wibowo, Agus. 2013. Manajemen Pendidikan Karakter di Sekolah (Konsep dan Praktik Implementasi). Yogyakarta: Pustaka Pelajar. 